Article

\title{
Assessing of Losses and Dilution Impact on the Cost Chain: Case Study of Gold Ore Deposits
}

\author{
Mikhail Marinin ${ }^{1}$, Oksana Marinina ${ }^{1, *(\mathbb{D})}$ and Radosław Wolniak ${ }^{2}$ (D) \\ 1 Saint Petersburg Mining University, 199106 Saint Petersburg, Russia; Marinin_MA@pers.spmi.ru \\ 2 Silesian University of Technology, 44-100 Gliwice, Poland; radek_wol@o2.pl \\ * Correspondence: Marinina_OA@pers.spmi.ru
}

Citation: Marinin, M.; Marinina, O.; Wolniak, R. Assessing of Losses and Dilution Impact on the Cost Chain: Case Study of Gold Ore Deposits. Sustainability 2021, 13, 3830. https:// doi.org/10.3390/su13073830

Academic Editor: George Banias

Received: 11 March 2021

Accepted: 28 March 2021

Published: 31 March 2021

Publisher's Note: MDPI stays neutral with regard to jurisdictional claims in published maps and institutional affiliations.

Copyright: (c) 2021 by the authors. Licensee MDPI, Basel, Switzerland. This article is an open access article distributed under the terms and conditions of the Creative Commons Attribution (CC BY) license (https:// creativecommons.org/licenses/by/ $4.0 /)$.

\begin{abstract}
The conditions of declining gold grade in the ore, increasing depth of excavation, and de-creasing unallocated stock of deposits make it necessary to develop efficient solutions for the mine-to-mill process, which have to be adapted to each specific mining plant and will optimizes production costs. Current research focuses on a case study that demonstrates how indicators of mining losses and dilution influence the variation of costs chain in the production cycle. The article examines the topical issue of determining the effects at the mine-to-mill stages due to changes in losses and dilution. The author's approach to the formation of a mine-to-mill cost chain is proposed by integrating several cost estimation methods into the general cost estimation methodology. The estimation methodology is a compilation of factor analysis and cost engineering methods that take into account the change in costs due to the variation of losses and dilution. It was proven that with variations in losses and dilution, cost savings arise due to changes in the volume of work on ore averaging, ore transportation, and beneficiation. For the case of the Kuranakh ore field, there are no effects at the mining stage. The use of internal reserves by means of managing ore quality parameters allows reducing the costs per ton of processed rock mass along the entire production chain.
\end{abstract}

Keywords: cost optimization; mine-to-mill; mineral losses; dilution; average grade; quarry; gold mining

\section{Introduction}

Modern gold mining companies in Russia and worldwide come across problems of production costs optimization caused by severe price competition on the one hand and deteriorating mining and geological conditions on the other, including declining gold grade in the ore, increasing depth of excavation, decreasing unallocated stock of deposits, etc.

Just a few mining companies can change the situation by means of extensive production development, namely due to acquisition of new deposits, application of highperformance equipment and modern technologies. Therefore, mining companies tend to pay more attention to internal reserves of efficient subsoil use and optimal resource consumption, based on continuous planning, analysis and control of the production process, starting from extraction of mineral resources and finishing with their processing (Mine-to-Mill process) [1-5].

That is why, presently, there is a need to develop efficient solutions of the mine-to-mill process, which has to be adapted to each specific mining plant. The idea of the mine-tomill concept is that metal production is a chain of interconnected processes (extractiontransportation-communition-processing), and completion of each stage affects the following ones. Therefore, input engineering parameters of the previous process determine technological and economic indicators of the succeeding one, i.e., expenditure chain of the production cycle.

Engineering parameters include a wide range of factors that depend on geology, mining method and technique, grain composition of the rock mass, transportation schemes, technology of ore blending, etc. This research focuses on a case study that demonstrates 
how indicators of mining losses and dilution (extraction stage parameters) influence variation of costs in the production cycle [6,7].

Case study: Kuranakh ore field contains 11 deposits: Severnoye, Porfirovoye, Tsentralnoye, Yakutskoye, Bokovoye, Pervukhinskoe, Kanavnoe, Delbe, Dorozhnoye, Yuzhnoye, Novoye its total area is around $1500 \mathrm{~km}$ [8]. The gold reserves at the deposits of the Kuranakh group included: explored ( $\mathrm{ABC} 1$ categories) - 78.6 tons, preliminary estimated (C2) - 6.8 tons, with an average gold grade in the ore of 1.58-2.83 g/t (average for all deposits-2.01 g/t) $[9,10]$. The study considers two mining conditions: base-case scenario and project scenario. The base-case scenario implies the actual conditions of the Kuranakh ore field development. Such factors as relatively small reserves, complex morphology and non-compact arrangement of ore bodies, which are significantly remote from each other and from concentration plants (up to $20 \mathrm{~km}$ ), cause scattered (decentralized) mining operations and require increased transport standards, additional costs for the construction and maintenance of open pit roads, dump facilities, industrial sites.

Extremely uneven mineralization and distribution of metal content, frequent intermittency of ore and waste rocks in ore bodies and deposits require additional costs for in-mine exploration, testing of blast boreholes, ore blending prior to its processing (organization and maintenance of an in-between stockpile) and selective mining of industrial, cut-off grade (poor) ores and waste rocks.

If we assume that we change technological parameters, for example, we use selective mining, then first of all we increase the content in industrial reserves and reduce losses and dilution. This allows us to accept the project scenario. The indicators of the base-case and project scenarios differ in the characteristics of losses and dilution: base-case scenario: losses are $3.1 \%$ with the ore grade of $0.9 \mathrm{~g} / \mathrm{t}$; dilution is $17 \%$ with the grade of $0.2 \mathrm{~g} / \mathrm{t}$; project scenario: losses are $2.1 \%$ with the ore grade of $0.9 \mathrm{~g} / \mathrm{t}$; dilution is $13 \%$ with the grade of $0.2 \mathrm{~g} / \mathrm{t}$.

Basing on factor analysis and method of value engineering, a methodology is developed that allows detecting cost economy in the process of production, which arises due to the influence of losses and dilution factors. The goal of this approach is to estimate the possibility of intensive development for gold mining companies using internal reserves of cost minimization per ton of processed ore. Effect of cost minimization due to variation of losses and dilution parameters (initial parameters of the extraction process) is manifested as changes in gold grade of the extracted rock mass, changes in the amounts of ore blending and transportation, changes in the amount of ore processing.

\subsection{Mine-to-Mill Concept}

Mine-to-Mill (translated from English as "from mine to factory") is a methodology that focuses on the development of an integrated strategy for optimizing production, crushing of ore, as well as its further grinding, in order to reduce costs per ton of ore and increase profitability of production.

Mine-to-mill links aspects of mining industry to mineral processing. The goal of this linking is optimization of all processing stages. When the concept is effectively implemented, it can bring huge productivity gains in the range of 10-20\% [11].

Therefore, starting in the 1990s, the concept of "Mine-to-Mill" was formed, which is based on the task of effectively combining the processes of extraction and enrichment, as well as on the total cost of production instead of the cost of individual operations. The first simulation studies and research projects, based on the mine-to-mill concept, started in the 2000s. From the 2010s the mine-to-mill concept has been used as a production tool and an ongoing population of block model with orebody and processing parameters [11].

According to McCaffery [12], mine-to-mill is really just a code for making effort and putting the processes in place to record, in an accessible format, an understanding of the orebody, how changes in the orebody and operating practice drive productivity and production, and understanding the operating parameters in the mine and mill, which can be manipulated to improve productivity and operating costs. 
The other definition, made by Adel, is concentrated on energy consumption. In his concept, mine-to-mill is a holistic approach to the optimization of mining and processing operations. It attempts to minimize energy consumption of particle size reduction processes [13].

Another definition was made by Scott. According to him, mine-to-mill is an improvement that involves optimizing the chain of rock breakage process from the in situ rock in the mine to the output of the concentrator [14].

Development of the mine-to-mill concept was carried out by foreign studies in the framework of the following issues:

- Simulation studies on the relationship between fragmentation and throughput of a SAG mill $[15,16]$;

- Ore hardness indicators [17] and geotechnical parameters in mine block models and subsequent optimization of mill productivity [18];

- Integrated communication modeling systems for blasting, grinding and flotation $[19,20]$.

Many researchers tried to develop a methodology to analyze and optimize the whole production process in the mine [21]. For example, they introduced the concept of a holistic approach to mine-to-mill process optimization. Using this concept, authorities of the company could achieve an increase in profitability [22]. Those mine-to-mill optimization concepts were based on many case studies, for example, open pit mining [23] or pit-to-plant operations [24].

The ultimate goal of mine-to-mill optimization is to improve the energy efficiency of rock breakage by optimizing blast fragmentation $[25,26]$. Crushing and grinding in the mines are some of the most energy-intensive processes in the industry. Rock breakage comprises of about $30-60 \%$ of total energy consumption in the mines. Because of that, this process impacts not only energy consumption, but total mine productivity. An improvement of this process can be made using mine-to-mill optimization [27]. The common goal of many mine-to-mill studies is whole mill performance [28-30], but some authors concentrate on drilling and blasting performance [31-33].

The use of the mine-to-mill concept is very beneficial for organizations. First, we can achieve many productivity benefits using it. Analyses were made in many countries including Canada, Argentina, Papua New Guinea, Australia, USA, Indonesia, Peru, Chile, Laos, Ghana, Mali, and Mongolia; these found the product increase to be mainly at 10-20\%, but in some cases up to $60 \%[34,35]$.

Using assets available in the organization, we can maximize production volume and minimize the cost per ton. Because of this concept, we can establish the integrated mining strategy and processing strategy. This strategy should be tailored to particular organizations. Using this concept, and integrating all company activities we can achieve substantial saving. Other important benefits of mine-to-mill implementation are connected with the production process itself [36]. Some studies also note the possibility of energy benefits achieved from mine-to-mill implementation [37,38]. Using it, we can improve the blasting fragmentation and also improve downstream processing performance. The finer ore fragmentation leads to following positive impacts of the concept's implementation [39]: increasing haulage and shovel productivity, decreasing of the wear rates in shovel components and decreasing of wear rates in the case of rock breaker and primary crusher wear components. Using the mine-to-mill concept leads to introduction of the measurement of many processes within the organization. The measurement leads to understanding of what actually is most important. In this way, we could provide the greater predictability of the process. The proper measurement system can bring also other benefits because of the possibility of throughput forecasting and geometallurgical modeling [5].

Besides many benefits connected with the mine-to-mill concept has also some weaknesses and problems with the implementation of the process. The first problem is connected with over-simplification of the concept. Because the whole mine-to-mill concept is very complex some organizations tend to concentrate only on selected aspects. This over-simplification is sometimes based on the statement that in the mine the increase of 
explosive consumption can lead to entire chain value optimization, because of that organization's tendency not to increase blast intensity. We can note that some organizations have problems with mine-to-mill concept's reconciliation over longer period of time. Those problems can follow poor reconciliation between the mill and grade control prediction [40]. Sometimes, there is some incorrectness in the application of resource modeling methods it can lead to poor analysis of a mill capacity at the first stage of operations [41].

In Table 1, we summarize the main strengths/benefits of the mine-to-mill concept implementation and the weaknesses/problems with it. We think that benefits of the mineto-mill implementation prevail, as the weaknesses are connected mainly not with the concept itself but with the bad implementation on the part of the organization. We think that to achieve benefits and to avoid problems organization should implement the concept in complex, holistic way. Without such an approach, we can spot some problems which can lead to weaknesses with the concept's implementation.

Table 1. Strengths/benefits and weaknesses/problems of mine-to-mill concept implementation. Sources: [4,5,35-41].

\begin{tabular}{|c|c|}
\hline Strengths/Benefits & Weaknesses/Problems \\
\hline $\begin{array}{ll}\checkmark & \text { Productivity benefits } \\
\checkmark & \text { Maximization of production/performance improvement } \\
\checkmark & \text { Minimization of the cost per tone } \\
\checkmark & \text { Establishment of the integrated mining strategy adjusted } \\
& \text { to organization } \\
\checkmark & \text { Potential for optimization of blasting fragmentation } \\
\checkmark & \text { Energy benefits } \\
\checkmark & \text { Achievement of substantial savings } \\
\checkmark & \text { Downstream processing performance } \\
\checkmark & \text { Introduction of measurement } \\
\checkmark & \text { Throughput forecasting and geometallurgical modeling }\end{array}$ & $\begin{array}{ll}\checkmark & \text { Over-simplification of the concept } \\
\checkmark & \text { Organization not increase blast intensity } \\
\checkmark & \text { Problems with concept's reconciliation over longer period } \\
\checkmark & \begin{array}{l}\text { of times } \\
\text { Incorrectness in the application of resource modeling } \\
\text { methods }\end{array}\end{array}$ \\
\hline
\end{tabular}

\subsection{Quality Control: Losses, Dilution, Average Grade of the Valuable Component}

Gold ore mining is very beneficial from an economic point of view. However, in order to maximize profits, recovery of products needs optimization [42]. A very important factor in this process is the impact of particular ore type and its characteristics on the head grade [43]. In gold processing, all mining and processing operations involve series of sequential stages. Those stages should be complementary, and one operation is affecting another one. To achieve optimization of the whole process, it is not sufficient to optimize each function separately. The whole process of ore extraction should be taken into consideration.

We can distinguish two types of mine-to-mill integration. One is operational and the second one is physical [44].

Operational integration concentrates on:

- use of drill and shovel technologies to monitor processes,

- optimization of blast fragmentation,

- optimization of communition processes,

- improvement of monitoring in the factory, especially of the handling system in the pit and ore.

Physical integration concentrates on:

- fragment size classification,

- improvements of grade control,

- sorting,

- improvement of mill feed grades.

At present, it is not easy to find detailed information on ore losses and dilution in the mines worldwide, especially in case of gold mines. 
Figure 1 demonstrates a theoretical model of mine-to-mill integration for a gold mine based on the Xingwana concept [45]. In this model, three main components of the integration of mine-to-mill can be distinguished: fragmentation, ore loss and dilution. Their main characteristics are described in Table 2.

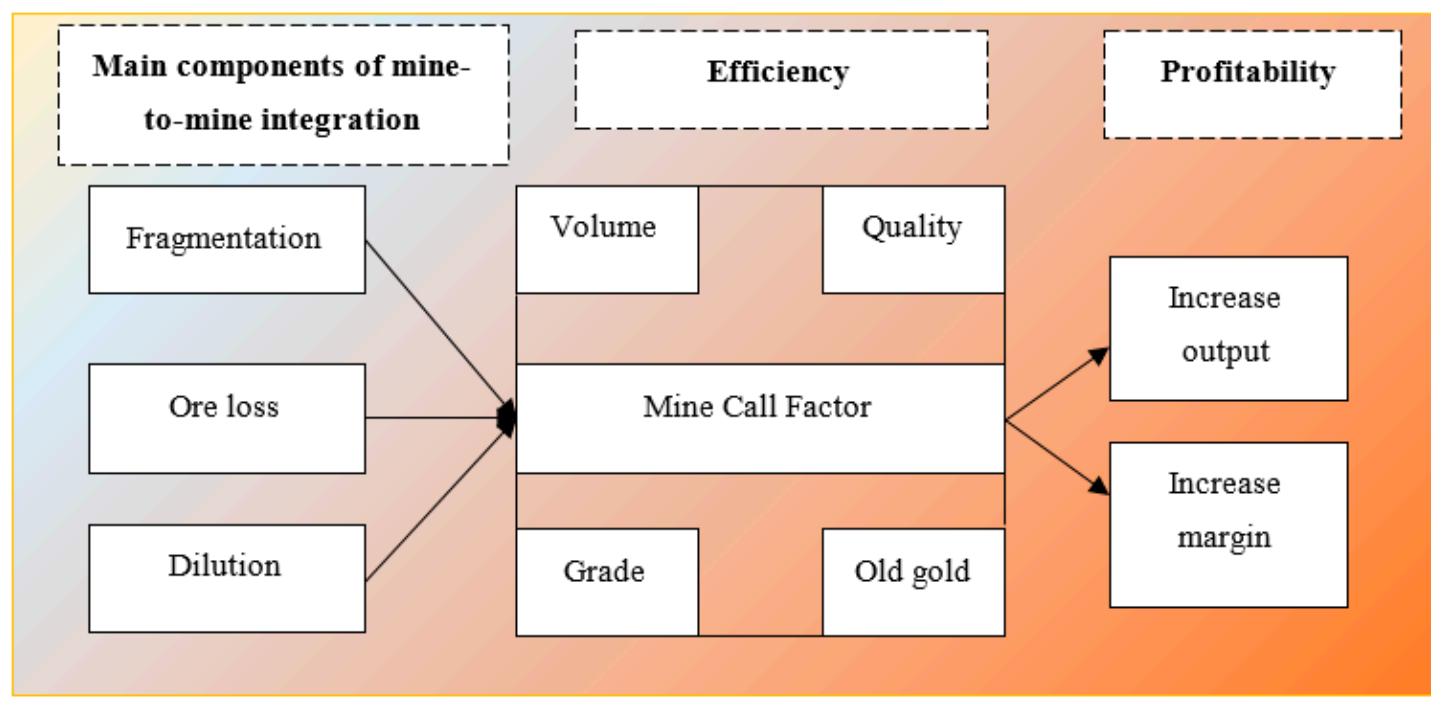

Figure 1. Theoretical model of mine-to-mill integration in a gold mine. Source: [45].

Table 2. Main components of mine-to-mill integration in a gold mine. Sources: [45-53].

\begin{tabular}{|c|c|}
\hline Component & Characteristics \\
\hline Fragmentation & $\begin{array}{l}\text { Fragmentation can be defined as the size distribution of rock fragments. The fragmentation is } \\
\text { dependent on factors such as rock properties, charge patterns, specific drill spacing, gas explosion } \\
\text { pressure and properties of explosives. } \\
\text { Blasting is used to produce rock fragments that are manageable. It is important to easy clean them, } \\
\text { handle, load, or crush. Those processes are used to minimize total production cost per ton blasted. } \\
\text { The process of ore movement is realized by means of face cleaning, blasting, loading, and scraping. } \\
\text { In some cases, realization of those processes leads to ore loss. Ore losses can be defined as any } \\
\text { unrecoverable economic ore, which is left inside the stope, or which is not recovered, using mineral } \\
\text { processing system. } \\
\text { This is broken ore, which was called by mine measuring methods, but for now was not removed and } \\
\text { not incorporated in the accounting system. Also, ore losses occur when some valuable material is } \\
\text { misclassified, for example, as a waste and is sent to waste dumps. } \\
\text { When the material is broken from the stope, it is a mixture of waste rock and reef. The proportion } \\
\text { between waste and reef depends on many factors, such as waste width, reef width, intrusions, faults } \\
\text { and also mining practices, in particular ore mine. Dilution may be an effect of low-grade material } \\
\text { mixing or waste mixing with the ore. This can occur during the operation and then be sent into } \\
\text { processing. The effect is reduction of the ore value and waste of material. } \\
\text { We can quantify dilution as the ratio of tonnage of waste mined, which was sent to the mill, to the } \\
\text { whole tonnage of ore plus whole waste milled. It can be expressed as percentage: } \\
\text { Dilution= } \text { Waste tons } \\
\text { Ore plus waste tons } \\
\text { p } 100\end{array}$ \\
\hline
\end{tabular}

Modern studies of assessing the impact of losses and dilution on the economic efficiency of mining companies are focused on defining technological tasks and do not consider in its entirety the possibility of reducing costs along the technological chain.

One of the methodologies used in the process is the Process Integration and Optimisation (PIO) methodology, developed in Metso Minerals Process technology Asia-Pacific. This methodology is based on the following steps [54]:

- Delineation and characterization of main domains, based on rock strength and structure. At this stage an organization can use many measurement techniques, which are statistically representative. 
- Establishment of process constraints, such as: damage and control, wall stability, presence of water, muckpile characteristics, ore dilution, size of mining equipment, process bottlenecks, power of crushing, and mining equipment.

- Definition of downstream requirements, which are key to the process and development of proper drilling or blasting strategies for each domain.

- Usage of proven software tools, simulations, and predictive models to establish good level of operating and control strategy to increase and maximize overall profit from the mill.

- Implementation and monitoring of integrated operating strategies and establishment of proper standards, for example, quality standards.

- Analysis of data and results.

- Implementation and maintenance of obtained benefits in the long term perspective.

Based on his concept, Metso Minerals Process technology Asia-Pacific optimized and increased efficiency of their processes in each domain.

In one of the first studies on the mine-to-mill concept, authors described its use at an operating quarry. The effects were based on the improvement of systematic assessment of crushing and screening processes, as well as on the improvement of performance in size distribution and particle shape of the final products [55].

In his paper [56], Pease, J.D., described positive effects of using this concept in leadzinc operations. The result of mine-to-mill implementation was lower tonnage of ore, which was mined and processed at the plant. They also noted improvement in controllability and better metallurgical performance of the flotation circuit. Besides, the authors observed improved economics of the operations in the company.

Many studies were conducted in organizations such as KCGM in Western Australia, Porgera in Papua New Guinea, Highland Valley in British Columbia, and Cadia Hill in New South Wales. Improvements in the mill throughput were in the range of 10-15\% [57-60]. For example, in KCGM it was $14 \%$, in Porgera-15\%, in Highland Valley-10\% and in Cadia Valley-14\%.

A very interesting study, made by Erkayaoglu and Dessureault, showed positive effects of mine-to-mill implementation in case of data warehousing and data mining [61]. They showed that each stage in the value chain of the mine process had parameters that affected product quality. Using real-time data in warehousing and data mining, we can help decision makers in the organization and improvement of mine-to-mill value chain.

A new case of mine-to-mill optimization was described on the example of hard-rock mine by Junhyok and Kwangmin. Their study shows that it is possible to use drilling performance data as a part of mine-to-mill efforts. It can be useful to determine an optimal blast energy design by determination of target fragmentation and due to controlling of the blast fragmentation [27].

Modern studies on the assessment of how ore losses and dilution affect economic efficiency of mining companies focus on definition of engineering tasks and do not give comprehensive consideration to the possibilities of cost reduction in the production chain. This research suggests an approach, which integrates cost indicators throughout the whole production cycle from ore extraction to its processing, as well as ore quality criteria. What is understood under quality is the combination of product properties that meet the standards and technical conditions (e.g., grade of valuable components and impurities, grain composition, ore processability, etc.). In this research, the input parameter is the grade of the valuable component (gold) in the ore at the stages of extraction, transportation, and processing. The grade of the valuable component is estimated basing on the parameters of mining losses and dilution $[62,63]$.

Product quality management is a complex of organizational, technical, and economic measures that exert a goal-oriented influence on the product quality. The process of mineral product quality management is composed of multiple stages. First the deposit is outlined; directions and procedure of mining development are selected. The possibilities of quality management are to a great extent defined by the system of mining. The quality of mineral 
resources is directly affected during ore extraction, transportation, production, storage, and shipment to the consumer. At the same time, control activities, which can improve the quality of mineral resources in the process of mining, are relatively limited (an increase in product concentration in the initial raw material is mostly achieved either by enrichment or by primary processing). They include reduction of dilution and losses by improving the technology and organization of mining operations and by application of new technical means of mining production. Absolute increase or decrease in the average grade of a component in the extracted material is achieved by mineral reserves management-rational engagement of richer or poorer ores [64-66].

Foreign researchers in the area of ore quality assessment Abdollahisharif, J. et al. [67], Barr, D. [68], Beck, D. [69], Hall, B. [70], Rendu, J.M [71], Bootsma, M.T. et al. [72], and Ahmadi, M.R., Bazzazi, A.A. [73] focused on the calculation of cut-off grade (CG) to estimate the efficiency of resource development, which is predetermined by the necessity to optimize extraction strategy taking into account market volatility. Studies associated with the analysis of the impact that losses and dilution exert on the ore quality in publications by Whillans, P.T. [74], Elbrond, J. [75], and Hassan, Z. Harraz [76] are limited to engineering estimations and do not take into account economic aspects.

Mining companies in Russia and most CIS countries in their CG calculations rely on the main provisions of the Methodology [77] and have no right to set their own CG values for ore samples and mining blocks. In case of necessity, they can only present and approve techno-economic assessment (TEA) of exploitation conditions, applicable to a certain subsoil area; they can be extended to the next term, but only after approval of the State Commission on Mineral Reserves (GKZ). The method of CG estimation in the Russian practice differs from the international one; as explained in the studies by Kapustin, Yu.A. [78], Nesis, N. [79], Fomin, S.I. [6], Rudenko, V.V. [80], it is designed to serve institutional interests and does not allow companies to use this tool in their shortterm planning. In Russia for the planning of mining operations, companies use several characteristics, describing the grade of the valuable component (metal in the ore): cutoff grade in the subsoil ( $\left.C G_{\text {subsoil }}\right)$, used for mineral resources estimation; content in the extracted diluted ore $\left(C_{\text {ore }}\right)$; metal content sent to the mill $\left(C_{\text {Mill }}\right)$ [81].

\section{Materials and Methods}

The problem, stated in the paper, is associated with estimation of how losses and dilution parameters impact the costs of gold extraction and processing in case of open pit mining in the ore field, containing a group of deposits. Changes in the structure of losses and dilution determine the ratio between the amounts of production and overburden removal, as well as average grade of the ore, which affect the entire technological chain starting from ore extraction and finishing with its processing, including all the processes in-between, such as transportation and stacking.

Research design:

1. The 'Introduction' section reviews theoretical foundations of such terms as quality control, losses, dilution, average and cut-off grades of mineral raw materials. The main references are presented, which reflect the aim and objectives of the mine-to-mill concept.

2. The 'Results' section demonstrates the research method, which includes stages that estimate how losses and dilution indicators influence the costs of gold extraction and processing in open-pit mining. Study materials include commercial reserves and gold grade in the group of gold deposits at Kuranakh ore field. The assessment method is a compilation of several guidelines: estimation of the average metal content in the extracted ore; the estimation of Owing and Operating [82]; evaluating the efficiency of mining and processing by reducing costs. Section contains the following calculations of mine-to-mill chain:

- Estimation and analysis of average grade of the valuable component in the ore, considering changes in the indicators of losses and dilution; 
- Economic effect from reduction of operating costs on ore transportation from the quarry to the processing plant due to changes in the amount of ore stacking;

- Justification of techno-economic indicators of gold processing plant (GPP) performance.

3. The 'Discussion' section describes the main possibilities and limitations of the suggested approach to losses and dilution estimation, demonstrates case studies of gold mining companies, applying mine-to-mill approaches.

Case study: Kuranakh ore field contains 11 deposits: Delbe, Kanavnoye, Yakutskoye, Dorozhnoye, Tsentralnoye, Porfirovoye, Bokovoye, Severnoye, Yuzhnoye, Yuzhnoye, and Novoye [8].

To estimate average metal content in the extracted ore, the following values of commercial and non-commercial reserves were taken for the Kuranakh ore field (Table 3).

Table 3. Values and structure of commercial reserves of the deposits at Kuranakh ore field. Source: [8-10].

\begin{tabular}{|c|c|c|c|c|}
\hline \multirow{2}{*}{ Deposit } & \multirow{2}{*}{$\begin{array}{l}\text { Share in the Structure of Commercial } \\
\text { Reserves of Kuranakh Field, \% }\end{array}$} & \multicolumn{3}{|c|}{ Characteristics of Commercial Reserves } \\
\hline & & Ore, Thousand Tons & Au Grade, g/t & $\mathrm{Au}, \mathrm{kg}$ \\
\hline Delbe & 25.60 & $38,149.63$ & 1.35 & $51,502.00$ \\
\hline Kanavnoye & 18.20 & $27,122.00$ & 1.21 & $32,817.62$ \\
\hline Yakutskoye & 14.70 & $21,906.23$ & 1.24 & $27,163.73$ \\
\hline Dorozhnoye & 11.00 & $16,392.42$ & 1.19 & $19,506.98$ \\
\hline Tsentralnoye & 10.10 & $15,051.22$ & 1.51 & $22,727.35$ \\
\hline Porfirovoye & 5.80 & 8643.28 & 2.44 & $21,089.59$ \\
\hline Bokovoye & 5.00 & 7451.10 & 1.62 & $12,070.78$ \\
\hline Severnoye & 4.50 & 6705.99 & 1.23 & 8248.37 \\
\hline Pervukhinskoye & 3.20 & 4768.70 & 1.19 & 5674.76 \\
\hline Yuzhnoye & 1.80 & 2682.40 & 1.28 & 3433.47 \\
\hline Novoye & 0.10 & 149.02 & 1.42 & 211.61 \\
\hline TOTAL & 100.00 & $149,022.00$ & 1.37 & $204,446.26$ \\
\hline
\end{tabular}

Indicators of losses and dilution are examined under two scenarios:

- base-case scenario: losses are $3.1 \%$ with the ore grade of $0.9 \mathrm{~g} / \mathrm{t}$; dilution is $17 \%$ with the grade of $0.2 \mathrm{~g} / \mathrm{t}$;

- $\quad$ project scenario: losses are $2.1 \%$ with the ore grade of $0.9 \mathrm{~g} / \mathrm{t}$; dilution is $13 \%$ with the grade of $0.2 \mathrm{~g} / \mathrm{t}$.

The base-case scenario implies actual conditions of gold mining company operation, taking into account existing regulations on the estimation of losses and dilution.

The project scenario provides variations in the indicators of losses and dilution and implies that their values should be as close as possible to the regulatory limits.

Project scenario is distinguished from the base-case one by a $1 \%$ loss reduction. Estimation of dilution, associated with loss reduction, is based on the methodology $[62,83,84]$, which takes into account variable conditions of ore losses in the near-contact zone and pinch-outs, ore losses in waste disposal dumps in the process of overburden removal, etc.

Estimation of the average grade of the valuable component involves calculation of specific amounts of metal under base-case and project scenarios in the group of deposits at Kuranakh ore field basing on their structure in the total reserves. The analysis is based on comparison between the grade and yield of metal by varying the indicators of losses and dilution under different scenarios.

\section{Results}

The estimation methodology is a compilation of factor analysis and cost engineering methods that take into account the change in costs due to the variation of losses and dilution, Figure 2. It consists of several stages: 
1. Estimation and analysis of the average grade of the valuable component in the ore, considering changes in the indicators of losses and dilution.

2. Justification of the economic effect from reduction of operating costs on ore transportation from the quarry to the processing plant due to changes in the amount of ore stacking;

3. Justification of techno-economic indicators of GPP performance.

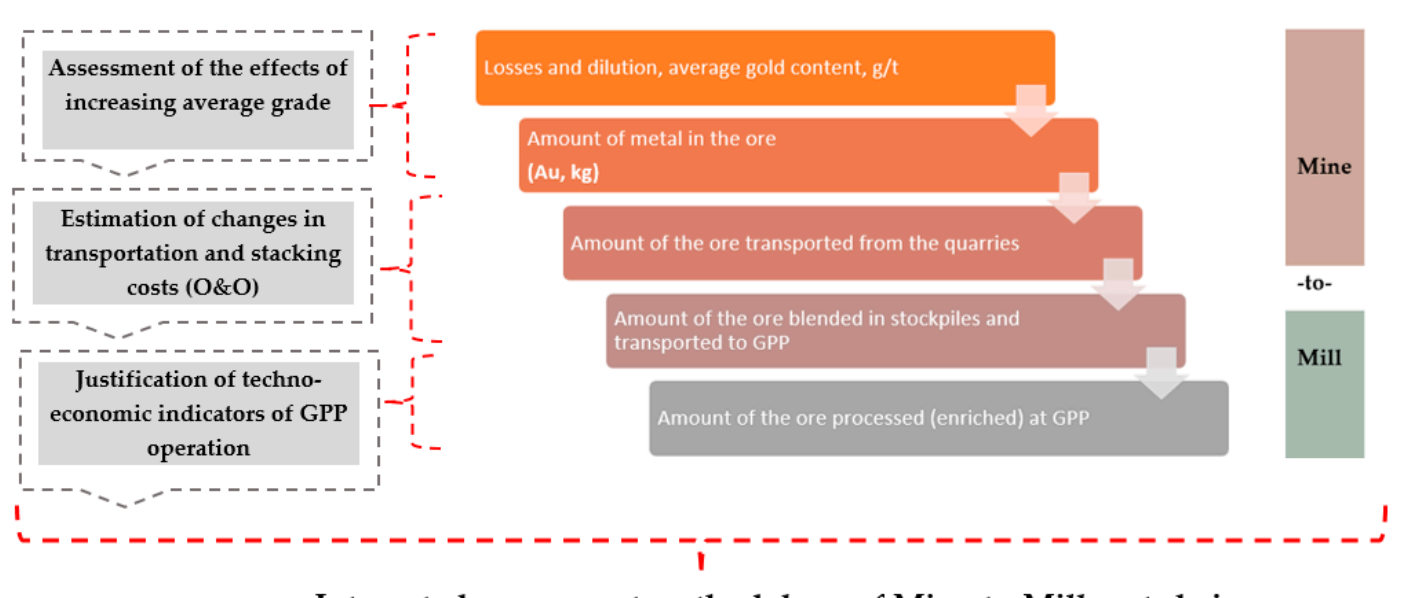

Integrated assessment methodology of Mine-to-Mill cost chain

Figure 2. Stages of mine-to-mill process and assessing of losses and dilution impact on the cost chain. Source: compiled by the authors.

3.1. Assessment of the Effects of Increasing Average Grade. Estimation and Analysis of the Average Grade of the Valuable Component in the Ore, Considering Changes in the Parameters of Losses and Dilution

Average metal content in the extracted ore is calculated using formula $[62,83,84]$ :

$$
C_{a v}=\frac{\left(B \cdot C_{B}-L \cdot C_{L}+R \cdot C_{R}\right)}{(B-L+R)}
$$

where

$B$ is commercial ore reserves, thousand $t$;

$L$ is mining ore losses, thousand $t$;

$R$ is mining ore dilution, thousand $t$;

$C_{B}, C_{L}, C_{R}$-are values of gold content in the commercial reserves, mining ore losses and diluting rocks.

According to estimations of average grade of the valuable component and metal yield for each deposit, calculated for varying indicators of losses and dilution, values of metal yield under base-case and project scenarios were 204,852.2 kg and 205,218.20 kg, respectively (Tables A1 and A2).

Analysis of the average grade, amounts of ore and metal under base-case and project scenarios demonstrate that reduction of mining losses led to a decrease in dilution, rising average gold grade in the ore and metal yield at each deposit. $1 \%$ variation of loss indicator (with the grade of $0.9 \mathrm{~g} / \mathrm{t}$ ) led to a $4 \%$ decrease in dilution volumes (with the grade of $0.2 \mathrm{~g} / \mathrm{t}$ ) and an overall increase in metal yield of $366 \mathrm{~kg}$ across all the deposits (Table A3).

A change in the quality of extracted ore, caused by an increase of metal grade in the ore due to precise definition of orebody outlines, led to changes in the workscope and types of work along the production chain, including transportation, handling operations, stacking and GPP processing. 
3.2. Justification of the Economic Effect from Reduction of Operating Costs on Ore Transportation from the Quarry to the Processing Plant Due to Changes in the Amount of Ore Stacking

Methodological recommendations for justification of the economic effect from reduction of operating costs on ore transportation have to take into account process procedures at GPP, working with the ore, blended (averaged) with respect to its lithological composition. For the conditions of current experiment, threshold gold grade in the ore was taken as $1.21 \mathrm{~g} / \mathrm{t}$.

Blending conditions at the stockpile are regulated by the flows, simultaneously coming from different gold deposits of Kuranakh ore field in accordance with annual plans and schedule of mining development.

Economic efficiency of measures, increasing gold grade in the ore due to variation of loss and dilution indicators, is estimated using the method based on value engineering of ore transportation and blending processes. Its economic effect lies in the economy of operating costs due to decreasing amounts of ore stacking and blending.

Handling expenses are based on the estimation of specific owning and operating costs of the equipment at the stage of stacking. They include:

- fixed operating costs, amortization expenses;

- labor costs of machine operators section (team), calculated using either actual (forecast) production rates or existing tariff rates of respective pay grades, taking into account allowances, perks, bonuses, and other extra payments;

- costs of high-wear parts replacement;

- costs of fuel, lubricants, and hydraulic fluids;

- repair and machine maintenance costs.

Ore transportation costs are calculated using formula [82]:

$$
\mathrm{C}_{t r}=\mathrm{T}_{t r}^{1}+\mathrm{T}_{t r}^{2}+\mathrm{T}_{t r}^{3}
$$

where $C_{t r}^{1}$ is the price of ore transportation from the quarry to the stockpile (stage 1), $\mathrm{rub} / \mathrm{tkm}$;

$\mathrm{T}_{t r}^{2}$ is the price of ore stacking and blending (stage 2), rub/t;

$\mathrm{T}_{t r}^{3}$ is the price of ore loading and transportation from the stockpile to GPP hopper (stage 3), $\mathrm{rub} / \mathrm{tkm}$.

$$
\mathrm{T}_{t r}^{j}=\mathrm{TCO}_{i j} / Q_{i j}
$$

where $T C O_{i j}$ is total cost of owning and operating [82] $i$ th type of equipment at $j$ th stage, rub;

$Q_{i j}$ is a workscope of $i$ th equipment at $j$ th stage, t.

$$
\mathrm{TCO}_{i j}=\sum^{J} \mathrm{O}_{i j}+\mathrm{C}_{i j}
$$

where $O_{i j}$ is owning cost of $i$ th type of equipment at $j$ th stage, rub/hr;

$Q_{i j}$ is amount of ore transportation by $i$ th type of equipment at $j$ th stage, tkm;

$C_{i j}$ is total operating cost of $i$ th type of equipment at $j$ th stage, rub.

The costs are conditionally variable and depend on the volume of ore. Owning and operating costs of a machine vary widely, as they depend on many factors: the nature of the work performed by the machine, the length of ownership, local prices for fuels and lubricants, operator costs, repair and maintenance costs, and transportation costs from the factory, interest rates, etc.

Owning cost $(\mathrm{O})$ equals a sum of initial (remaining) value of the equipment (including accessories) $(\mathrm{P})$, interest expenses $\left(\mathrm{O}_{e}\right)$, insurance charges $\left(\mathrm{O}_{r}\right)$ and property tax $\left(\mathrm{O}_{k}\right)$.

$$
\mathrm{O}=\mathrm{P}+\mathrm{O}_{e}+\mathrm{O}_{r}+\mathrm{O}_{k}
$$


Calculations of owning and operating costs are based on the actual terms of ownership and total productive life of the equipment.

Total operating cost $(C)$ is a sum of the following cost items: fuel $\left(C_{f}\right)$, tires $\left(C_{t}(x)\right.$, scheduled maintenance $\left(\mathrm{C}_{\mathrm{SM}}\right)$, repair $\left(\mathrm{C}_{\mathrm{rep}}\right)$, high-wear parts $\left(\mathrm{C}_{\mathrm{HWP}}\right)$ and planned payroll budget $\left(\mathrm{C}_{P B}\right)$ :

$$
\mathrm{C}=\mathrm{C}_{\mathrm{f}}+\mathrm{C}_{\mathrm{t}(\mathrm{x})}+\mathrm{C}_{\mathrm{SM}}+\mathrm{C}_{\mathrm{rep}}+\mathrm{C}_{\mathrm{HWP}}+\mathrm{C}_{P B}
$$

Logistics of quarry-haulage traffic includes:

- transportation of ore extracted in the quarry to the intermediate stockpile for blending;

- transportation of non-commercial ores and their storage in special low-grade stockpiles;

- transportation of ore to the GPP hopper.

Figure 3 depicts a simplified flow chart of ore transportation from the quarry to the intermediate stockpile for blending and to the GPP receiving hopper.

According to the flow chart in Figure 3, transportation of the valuable component from the quarries to the intermediate stockpile is carried out using heavy trucks, then a blended rock mass with a standard (for the GPP) grade of gold is formed in the stockpile, averaged ore is rehandled by the loaders and transported to the GPP receiving hopper. The stages of transportation, blending and stacking use different types of equipment and vehicles.

The cost of ore transportation is defined as a sum of tariffs across the stages of ore transition from the quarries to the intermediate stockpile and GPP. On a premise of increasing gold grade in the ore (due to changes in loss and dilution values), it is assumed that the number of blending, stacking, and partial rehandling operations will decrease. This implies reduction of operating costs due to changes in the workscope $\left(Q_{i j}\right)$ at the stages of ore transportation, stacking and blending.

Costs of stage 2-rehandling and formation of an intermediate stockpile-are not included in the transportation costs, a calculation unit of handling operations is $1 \mathrm{t}$ of cargo or $1 \mathrm{hr}$ of operations. Based on the assumption that it is possible to transport a part of the ore mass to the GPP excluding the blending stage, the economy of operating costs forms due to changes in the workscope at stages 2 and 3 (Figure 3)-ore blending and its transportation to the GPP.

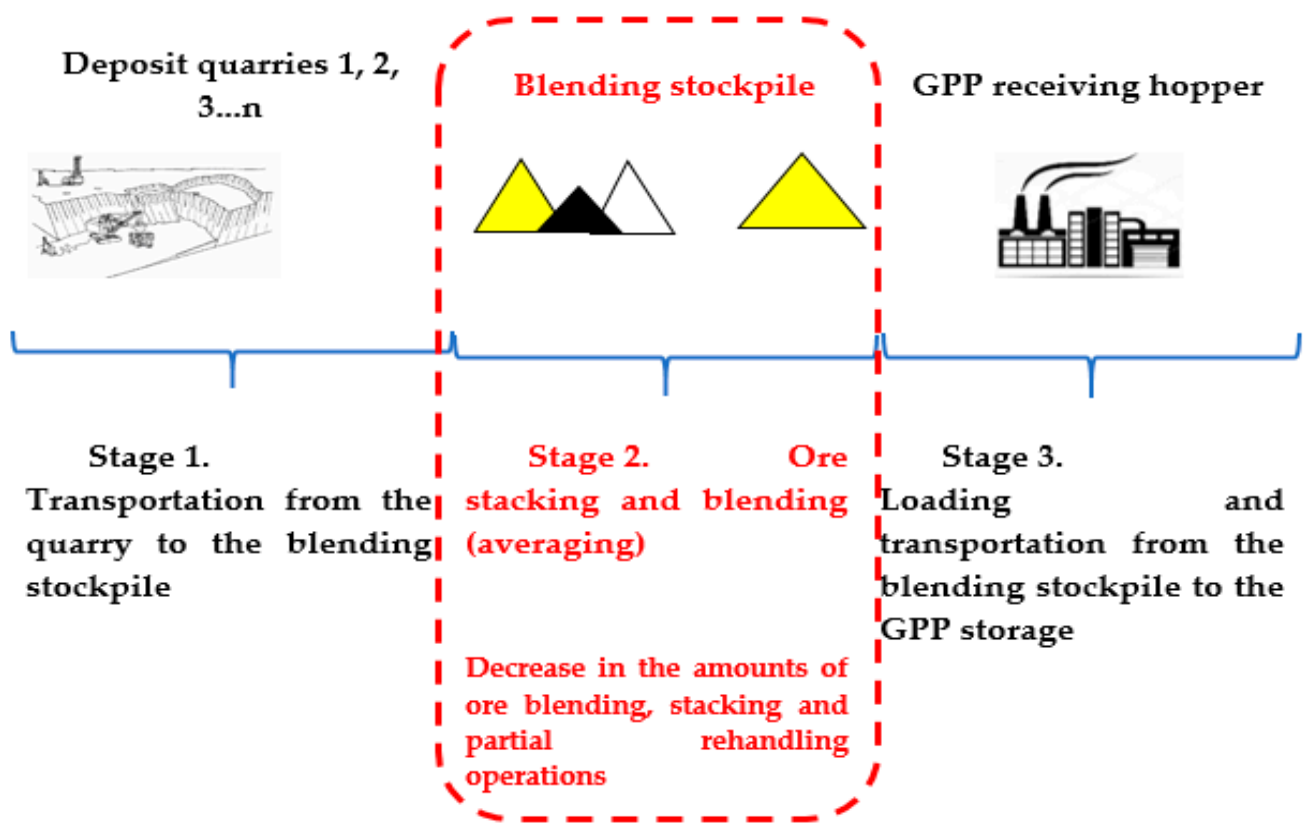

Figure 3. Costs chain of the production cycle. Simplified flow chart of ore transportation from the quarry to the intermediate stockpile for blending and to the GPP receiving hopper. Source: compiled by the authors. 
Estimation of economic efficiency is presented as an assessment of workscope susceptibility of the operating costs economy, caused by implementation of the project on orebody outlines adjustment. It is assumed that the workscope equals annual amount (6.0 million tons) of ore mass transportation to the GPP, estimation of economic efficiency is carried out for two types of equipment (CAT- R1600 H, CAT834), economy of operating costs is defined in the interval of workscope variation from $5 \%$ to $30 \%$, Table 4 .

Table 4. Susceptibility analysis: variation of operating costs due to changes in workscope at the transportation stages. Source: compiled by the authors.

\begin{tabular}{|c|c|c|c|c|c|c|c|}
\hline \multirow{2}{*}{$\begin{array}{l}\text { Type of } \\
\text { Equipment }\end{array}$} & \multirow{2}{*}{$\begin{array}{c}\text { Specific Labor } \\
\text { Tariff, \$/t } \\
\mathrm{T}_{t r}^{j}\end{array}$} & \multicolumn{6}{|c|}{$\begin{array}{c}\text { Economy of Operating Costs Due to Changes in Workscope }\left(Q_{i j}\right) \text { at the Stages of ore } \\
\text { Transportation, Stacking and Blending, } \$\end{array}$} \\
\hline & & $\begin{array}{c}Q_{i j} \\
(-5 \%)\end{array}$ & $\begin{array}{c}Q_{i j} \\
(-\mathbf{1 0} \%)\end{array}$ & $\begin{array}{c}Q_{i j} \\
(-\mathbf{1 5 \% )}\end{array}$ & $\begin{array}{c}Q_{i j} \\
(-20 \%)\end{array}$ & $\begin{array}{l}Q_{i j} \\
(-25 \%)\end{array}$ & $\begin{array}{l}Q_{i j} \\
(-30 \%)\end{array}$ \\
\hline $\begin{array}{c}\text { CAT- R } 1600 \\
\text { H }\end{array}$ & 0.40 & 121.5 & 243 & 364.5 & 486 & 607.5 & 729 \\
\hline CAT834 & 0.23 & 69.5 & 139.5 & 209.25 & 279 & 348.75 & 418.5 \\
\hline TOTAL & & 191.25 & 382.5 & 573.75 & 765 & 956.25 & 1147.5 \\
\hline
\end{tabular}

Analysis of project susceptibility indicators demonstrates that provided that amounts of extracted and transported ore fluctuate between $5 \%$ and 30\%, project efficiency due to reduced annual workscope of ore blending and loading can vary in the interval 191.25-1147.5\$.

\subsection{Feasibility Study of GPP Operation}

Amounts of ore extraction ( $D_{\text {ore }}$, thousand $t$ ) for GPP are estimated as follows $[62,83,84]$ :

$$
D_{\text {ore }}=B-\left(\frac{B \cdot L}{100}+\frac{B \cdot R}{100}\right)
$$

where $B$ is commercial ore reserves, thousand $t$;

$L$ is mining losses, thousand $t$;

$R$ is ore dilution, thousand $t$.

Economic effect under the project scenario is estimated as the economy of operating costs, as regards semi-variable costs of ore processing. Annual economy is estimated basing on the amount of processed ore.

Estimation of ore volumes, required to maintain productive capacity of the processing plant under varying indicators of losses and dilution, is presented in Table 5, where it is demonstrated that for every 1000 tons of processed ore under base-case scenario with 3.1\% losses and $17 \%$ dilution, under project scenario with $2.1 \%$ losses and $13.0 \%$ dilution, other grade conditions being equal, amounts of processed ore decrease by 30 tons. Amount of ore extraction ( $D_{\text {ore, }}$, thousand tons) for GPP is defined using the Formula (7).

Table 5. Feasibility study of the GPP—scenario comparison. Source: compiled by the authors.

\begin{tabular}{cccc}
\hline Indicator & Measuring Units & Base-Case Scenario & Project Scenario \\
\hline Commercial reserves & tons & 1000 & 1000 \\
Losses & $\%$ & 3.1 & 2.10 \\
Dilution & $\%$ & 17 & 13 \\
Amounts of ore, entering GPP $\left(D_{\text {ore }}\right)$ & tons & - & 1109 \\
to improvement in ore quality & tons & 4.0 & -30 \\
Cost of processing 1 ton of ore & USD & - & 4.0 \\
Economy of processing costs per 1 thousand tons of ore & USD & $6,000,000$ & 120.0 \\
Annual amounts of ore processing at GPP & tons & - & $6,000,000$ \\
Annual economy of costs & USD & $720,310.0$ \\
\hline
\end{tabular}


Reduced losses of the mineral product will lead to variation in the amount of processed ore due to changes in the structure of ore inventory. Economic effect under the project scenario is generated as a result of operating costs economy, as regards semi-variable costs of ore processing, and reaches $1200 \mathrm{USD} / \mathrm{t}$ at the cost of ore processing $4 \mathrm{USD} / \mathrm{t}$. Annual savings on processing of 6000 thousand tons of ore reach 720,310.0 USD.

\section{Discussion}

From the model above it follows that the changes in the structure of loss and dilution parameters determine the balance of volumes of production and overburden removal and the value of the average grade in the ore. Changes in the structure of losses and dilution have an impact on the operation of the entire technological chain, from the extraction stage to ore processing, including intermediate processes: transportation and stacking.

The main results obtained in this research confirm that for a gold company there is a possibility of intensive development through use of internal reserves of minimizing costs per 1 ton of processed ore. It is proved that the effect of cost minimization and increase in profits is achieved by variation of loss and dilution parameters and is manifested as changes in gold grade of the extracted rock mass, changes in the amounts of ore blending and transportation, and reduction in the amount of ore processing. These results confirm the possibility of using the proposed methodology in order to assess the impact of technological factors on the production chain of costing. The estimation methodology proposed in the study can be applied as a basis for modeling under operating conditions of other mining companies.

Results of research can be used in engineering surveys for justification of technological parameters in drilling and blasting (D\&B) projects, e.g., estimation of rock mass grain composition, definition of orebody outlines, etc. Precise estimation of loss and dilution parameters, as well as average grade of the ore flow, allows reaching a significant effect along the production chain, as proved in the study; it can become a reserve for increasing efficiency of gold mining companies, taking into account limited possibilities of extensive growth.

The advantage of the proposed method is that it integrates ore quality indicators and cost indicators of the whole technological cycle from extraction to processing.

The following conditions serve as restrictions for the research:

- The estimation method is invalid for complex deposits. Exploitation of complex deposits implies extraction of both main and associated minerals. As an outcome of mine-to-mill process, there are several types of products, e.g., commercial products of a complex gold ore deposit may include gold, silver, copper. This complicates estimation of operating and capital costs due to different prices of commercial products and different costs of their treatment.

- Estimation method is developed for specific logistical conditions of Kuranakh ore field deposits. Therefore, it requires adjustment in case it is applied at other deposits.

- The method considers the impact of only two technological parameters (losses and dilution) on the mine-to-mill chain. Other factors, dependent on geology, mining method and technique, grain composition of the rock mass, environmental cost, etc., are not taken into account.

In future studies, an extended set of factors will provide a more detailed assessment of the process; however, considering specific characteristics and unique nature of each deposit, the obtained results will only be of value on a case-by-case basis.

\section{Conclusions}

The goal of this research was to develop a methodological approach to the assessment of the influence that engineering factors exert on the production chain of costing from ore extraction to its processing. The following objectives were assigned in the study:

- theoretical analysis and identification of strengths and weaknesses of the mine-tomill concept, justification of the absence of thoroughly developed methodological foundations for the efficiency assessment of ore extraction parameter control; 
- development of guidelines for the assessment of how losses and dilution indicators influence the costing chain from ore extraction to its processing;

- practical evaluation of the guidelines for the case of gold ore deposits.

Based on the formulated objectives, the research justifies:

- the principle of economic assessment, based on continuous planning, analysis, and control of the production process from the stage of ore extraction to the treatment of the mineral product (mine-to-mill);

- the method of economic assessment as a compilation of factor analysis and value engineering, which takes into account the economy of operating costs due to variation of losses and dilution parameters throughout the whole production chain;

- results of economic assessment of how losses and dilution impact the indicators of operating costs (in a case study of the group of gold ore deposits), manifested as changes in the gold grade of the extracted rock mass, changes in the amounts of ore blending and transportation, decrease in the amount of ore processing.

The paper proves that changes in the structure of losses and dilution define the ratio between the amounts of production and overburden removal, as well as value of average grade in the ore, which affect functioning of the entire production chain, including the stages of ore transportation, blending (stacking) and processing. Estimation of the average grade of the valuable component includes calculation of specific metal amounts, based on the structure of total reserves, as well as comparison between the grade and yield of metal due to variations in the indicators of losses and dilution.

The main results of empirical study show that a decrease in the losses of mineral product will lead to variation in the amount of ore processing due to changes in the structure of ore inventory. Changes in the values of ore losses and dilution (3.1\% losses and $17 \%$ dilution under base-case scenario; $2.1 \%$ losses and $13.0 \%$ dilution under the project scenario) result in a 30 ton decrease in the amounts of processed ore. Under the project scenario, the economic effect takes place due to economy of operating costs, as regards semi-variable costs of ore processing.

The cost of ore transportation is defined as a sum of tariffs across the stages of ore transition from the quarries to the intermediate stockpile and GPP. From a premise of increasing gold grade in the ore, transported from the quarry and the intermediate stockpile, it is assumed that the amounts of ore blending, stacking and partial rehandling operations will decrease.

Estimation of economic efficiency is presented as an assessment of workscope susceptibility of the operating costs economy, caused by implementation of the project on orebody outlines adjustment. Analysis of project susceptibility indicators demonstrates that provided that amounts of extracted and transported ore fluctuate between $5 \%$ and $30 \%$, project efficiency due to reduced annual workscope of ore blending and loading can vary in the range of $191.25-1147.5 \$$.

Author Contributions: Conceptualization, M.M. and O.M.; methodology, M.M. and O.M.; software, M.M. and O.M.; validation, M.M. and O.M. and R.W.; formal analysis, M.M. and O.M.; investigation, M.M. and O.M. and R.W.; resources, M.M. and O.M.; writing—original draft preparation, M.M. and O.M.; writing—review and editing, R.W.; visualization, M.M. and O.M.; supervision, R.W. All authors have read and agreed to the published version of the manuscript.

Funding: This research received no external funding.

Institutional Review Board Statement: Not applicable.

Informed Consent Statement: Not applicable.

Acknowledgments: Special thanks for providing valuable guidance and financial support to the rector of St. Petersburg Mining University Litvinenko V.S.

Conflicts of Interest: The authors declare no conflict of interest regarding the results. 


\section{Appendix A}

Table A1. Estimation of the average grade and yield of metal (base-case scenario). Source: compiled by the authors.

\begin{tabular}{|c|c|c|c|c|c|c|c|c|c|c|c|c|}
\hline \multirow[b]{2}{*}{ Quarry } & \multicolumn{3}{|c|}{ Commercial Ore } & \multicolumn{3}{|c|}{ Losses, (Au 0.9 g/t) } & \multicolumn{3}{|c|}{ Dilution, (Au 0.2 g/t) } & \multicolumn{3}{|c|}{ Ore at the GPP } \\
\hline & $\begin{array}{c}\text { Thousand } \\
\text { Tons }\end{array}$ & $\underset{\text { Grade, g/t }}{\mathrm{Au}}$ & $\underset{\text { kg }}{\text { Au Metal, }}$ & $\begin{array}{l}\text { Thousand } \\
\text { Tons }\end{array}$ & $\%$ & $\underset{\text { Grade, kg }}{\mathrm{Au}}$ & $\begin{array}{c}\text { Thousand } \\
\text { Tons }\end{array}$ & $\%$ & $\underset{\text { kg }}{\text { Au Metal, }}$ & $\begin{array}{c}\text { Thousand } \\
\text { Tons }\end{array}$ & $\%$ & $\mathrm{Au}, \mathrm{kg}$ \\
\hline 1. Delbe & $38,149.63$ & 1.35 & $51,502.00$ & 1182.64 & 3.1 & 1064.37 & 6485.44 & 17.0 & 1297.09 & $43,452.43$ & 1.19 & $51,734.72$ \\
\hline 2. Kanavnoye & $27,122.00$ & 1.21 & $32,817.62$ & 840.78 & 3.1 & 756.70 & 3525.86 & 17.0 & 705.17 & $29,807.08$ & 1.08 & $32,060.92$ \\
\hline 3. Yakutskoye & $21,906.23$ & 1.24 & $27,163.73$ & 679.09 & 3.1 & 611.18 & 3724.06 & 17.0 & 744.81 & $24,951.2$ & 1.09 & $27,297.36$ \\
\hline 4. Dorozhnoye & $16,392.42$ & 1.19 & $19,506.98$ & 508.17 & 3.1 & 457.35 & 2786.71 & 17.0 & 557.34 & $18,670.97$ & 1.05 & $19,606.97$ \\
\hline 5. Tsentralnoye & $15,051.22$ & 1.51 & $22,727.35$ & 466.59 & 3.1 & 419.93 & 2558.71 & 17.0 & 511.74 & $17,143.34$ & 1.33 & $22,819.16$ \\
\hline 6. Porfirovoye & 8643.28 & 2.44 & $21,089.59$ & 267.94 & 3.1 & 241.15 & 1469.36 & 17.0 & 293.87 & 9844.69 & 2.15 & $21,142.32$ \\
\hline 7. Bokovoye & 7451.10 & 1.62 & $12,070.78$ & 230.98 & 3.1 & 207.89 & 1266.69 & 17.0 & 253.34 & 8486.8 & 1.43 & $12,116.23$ \\
\hline 8. Severnoye & 6705.99 & 1.23 & 8248.37 & 207.89 & 3.1 & 187.10 & 1140.02 & 17.0 & 228.00 & 7638.12 & 1.09 & 8289.27 \\
\hline 9. Pervukhinskoye & 4768.70 & 1.19 & 5674.76 & 147.83 & 3.1 & 133.05 & 810.68 & 17.0 & 162.14 & 5431.55 & 1.05 & 5703.85 \\
\hline 10. Yuzhnoye & 2682.40 & 1.28 & 3433.47 & 83.15 & 3.1 & 74.84 & 456.01 & 17.0 & 91.20 & 3055.25 & 1.07 & 3267.43 \\
\hline 11. Novoye & 149.02 & 1.42 & 211.61 & 4.62 & 3.1 & 4.16 & 25.33 & 17.0 & 5.07 & 169.74 & 1.25 & 212.52 \\
\hline TOTAL & $149,022.00$ & 1.37 & $204,446.26$ & 4619.68 & 3.1 & 4157.71 & $24,248.86$ & & 4849.77 & $168,651.18$ & 1.21 & $204,852.2$ \\
\hline
\end{tabular}

Table A2. Estimation of the average grade and yield of metal (project scenario). Source: compiled by the authors.

\begin{tabular}{|c|c|c|c|c|c|c|c|c|c|c|c|c|}
\hline \multirow{2}{*}{ Quarry } & \multicolumn{3}{|c|}{ Commercial Ore } & \multicolumn{3}{|c|}{ Losses, (Au 0.9 g/t) } & \multicolumn{3}{|c|}{ Dilution, (Au 0.2 g/t) } & \multicolumn{3}{|c|}{ Ore at the GPP } \\
\hline & $\begin{array}{l}\text { Thousand } \\
\text { Tons }\end{array}$ & $\underset{\text { Grade, g/t }}{\mathrm{Au}}$ & $\underset{\text { kg }}{\text { Au Metal, }}$ & $\begin{array}{l}\text { Thousand } \\
\text { Tons }\end{array}$ & $\%$ & $\underset{\text { kg }}{\text { Au Metal, }}$ & $\begin{array}{l}\text { Thousand } \\
\text { Tons }\end{array}$ & $\%$ & $\underset{\text { kg }}{\text { Au Metal, }}$ & $\begin{array}{l}\text { Thousand } \\
\text { Tons }\end{array}$ & $\%$ & $\mathrm{Au}, \mathrm{kg}$ \\
\hline 1. Delbe & $38,149.63$ & 1.35 & $51,502.00$ & 801.14 & 2.1 & 721.03 & 4959.45 & 13.0 & 991.89 & $42,307.94$ & 1.22 & $51,772.87$ \\
\hline 2. Kanavnoye & $27,122.00$ & 1.21 & $32,817.62$ & 569.56 & 2.1 & 512.61 & 3525.86 & 13.0 & 705.17 & $30,078.30$ & 1.07 & $32,305.02$ \\
\hline 3. Yakutskoye & $21,906.23$ & 1.24 & $27,163.73$ & 460.03 & 2.1 & 414.03 & 2847.81 & 13.0 & 569.56 & $24,294.01$ & 1.12 & $27,319.26$ \\
\hline 4. Dorozhnoye & $16,392.42$ & 1.19 & $19,506.98$ & 344.24 & 2.1 & 309.82 & 2131.01 & 13.0 & 426.20 & $18,179.19$ & 1.08 & $19,623.37$ \\
\hline 5. Tsentralnoye & $15,051.22$ & 1.51 & $22,727.35$ & 316.08 & 2.1 & 284.47 & 1956.66 & 13.0 & 391.33 & $16,691.81$ & 1.37 & $22,834.21$ \\
\hline 6. Porfirovoye & 8643.28 & 2.44 & $21,089.59$ & 181.51 & 2.1 & 163.36 & 1123.63 & 13.0 & 224.73 & 9585.39 & 2.21 & $21,150.96$ \\
\hline 7. Bokovoye & 7451.10 & 1.62 & $12,070.78$ & 156.47 & 2.1 & 140.83 & 968.64 & 13.0 & 193.73 & 8263.27 & 1.47 & $12,123.68$ \\
\hline 8. Severnoye & 6705.99 & 1.23 & 8248.37 & 140.83 & 2.1 & 126.74 & 871.78 & 13.0 & 174.36 & 7436.94 & 1.12 & 8295.98 \\
\hline 9. Pervukhinskoye & 4768.70 & 1.19 & 5674.76 & 100.14 & 2.1 & 90.13 & 619.93 & 13.0 & 123.99 & 5288.49 & 1.08 & 5708.62 \\
\hline 10. Yuzhnoye & 2682.40 & 1.28 & 3433.47 & 56.33 & 2.1 & 50.70 & 348.71 & 13.0 & 69.74 & 2974.78 & 1.11 & 3313.03 \\
\hline 11. Novoye & 149.02 & 1.42 & 211.61 & 3.13 & 2.1 & 2.82 & 19.37 & 13.0 & 3.87 & 165.27 & 1.29 & 212.67 \\
\hline TOTAL & $149,022.00$ & 1.37 & $204,446.26$ & 3129.46 & & 2816.52 & $19,372.86$ & & 3874.57 & $165,265.40$ & 1.24 & $205,218.20$ \\
\hline
\end{tabular}

Table A3. Analysis of average grade, amounts of ore and metal under various scenarios. Source: compiled by the authors.

\begin{tabular}{|c|c|c|c|c|c|c|c|c|c|}
\hline \multirow{3}{*}{ Quarry } & \multicolumn{3}{|c|}{ Base-Case Scenario } & \multicolumn{3}{|c|}{ Project Scenario } & \multicolumn{3}{|c|}{ Deviation } \\
\hline & $\begin{array}{l}\text { Amount of } \\
\text { Ore, Thousand } \\
\text { Tons }\end{array}$ & $\begin{array}{l}\text { Au Grade } \\
\text { in the } \\
\text { Commercial } \\
\text { Reserves, g/t }\end{array}$ & $\begin{array}{c}\text { Au } \\
\text { Metal, } \\
\text { kg }\end{array}$ & $\begin{array}{c}\text { Amount of } \\
\text { Ore, } \\
\text { Thousand } \\
\text { Tons }\end{array}$ & $\begin{array}{l}\text { Au Grade } \\
\text { in the } \\
\text { Commercial } \\
\text { Reserves, g/t }\end{array}$ & $\begin{array}{c}\text { Au } \\
\text { Metal, } \\
\text { kg }\end{array}$ & $\begin{array}{c}\text { Amount of ore, } \\
\text { Thousand } \\
\text { Tons } \\
{[4-1]}\end{array}$ & $\begin{array}{c}\text { Au Grade, } \\
\mathbf{g} / \mathbf{t} \\
{[5-2]}\end{array}$ & $\begin{array}{c}\text { Au Metal, } \\
\text { kg } \\
{[6-3]}\end{array}$ \\
\hline & 1 & 2 & 3 & 4 & 5 & 6 & 7 & 8 & 9 \\
\hline Delbe & $43,452.43$ & 1.19 & $51,734.72$ & $42,307.94$ & 1.22 & $51,772.87$ & -1144.49 & 0.03 & 38.2 \\
\hline Kanavnoye & $29,807.08$ & 1.08 & $32,060.92$ & $30,078.3$ & 1.07 & $32,305.02$ & 271.22 & -0.01 & 244.1 \\
\hline Yakutskove & $24,951.2$ & 1.09 & $27,297.36$ & $24,294.01$ & 1.12 & $27,319.26$ & -657.19 & 0.03 & 21.9 \\
\hline Dorozhnoye & $18,670.97$ & 1.05 & $19,606.97$ & $18,179.19$ & 1.08 & $19,623.37$ & -657.19 & 0.03 & 16.4 \\
\hline Tsentralnoye & $17,143.34$ & 1.33 & $22,819.16$ & $16,691.81$ & 1.37 & $22,834.21$ & -451.53 & 0.04 & 15.0 \\
\hline Porfirovoye & 9844.69 & 2.15 & $21,142.32$ & 9585.39 & 2.21 & $21,150.96$ & -259.3 & 0.06 & 8.6 \\
\hline Bokovoye & 8486.8 & 1.43 & $12,116.23$ & 8263.27 & 1.47 & $12,123.68$ & -223.53 & 0.04 & 7.5 \\
\hline Severnoye & 7638.12 & 1.09 & 8289.27 & 7436.94 & 1.12 & 8295.98 & -201.18 & 0.03 & 6.7 \\
\hline Pervukhinskoye & 5431.55 & 1.05 & 5703.85 & 5288.49 & 1.08 & 5708.62 & -143.06 & 0.03 & 4.8 \\
\hline Yuzhnoye & 3055.25 & 1.07 & 3267.43 & 2974.78 & 1.11 & 3313.03 & -80.47 & 0.04 & 45.6 \\
\hline Novoye & 169.74 & 1.25 & 212.52 & 165.27 & 1.29 & 212.67 & -4.47 & 0.04 & 0.1 \\
\hline TOTAL & $168,651.18$ & 1.21 & $204,852.2$ & $165,265.4$ & 1.24 & $205,218.2$ & -3385.78 & 0.03 & 366.0 \\
\hline
\end{tabular}

\section{References}

1. McKee, D. Understanding Mine to Mill; Cooperative Research Centre for Optimizing Resource Extraction: St Lucia, Brisbane, 2013; 96p.

2. Cameron, P.; Drinkwater, D.; Pease, J. The ABC of Mine to Mill and metal price cycles. In Proceedings of the AusIMM Mill Operators' Conference, Melbourne, Australia, 10-12 October 2016; pp. 349-358.

3. Wallace, G.; Morton, D. High Energy Bulk Explosives and Mine to Mill Focus-The Mt Rawdon Story. In Proceedings of the AusIMM Open Pit Operators' Conference, Kalgoorlie, Australia, 15-16 November 2016; pp. 60-69.

4. Nadolski, S.; Klein, B.; Scoble, M.; Connaughton, G. Energy benefits of implementing drill-to-mill strategies in open-pit copper mines. In Proceedings of the Copper 2013 International Conference, Santiago, Chile, 1-4 December 2013.

5. Dance, A.; Valery, W.; Jankovic, A.; La Rosa, D.; Esen, S. Maintaining the benefit-How to ensure Mine to Mill continues to work or you. In Proceedings of the Ninth Mill Operators' Conference, Fremantle, Australia, 19-21 March 2007; The Australasian Institute of Mining and Metallurgy: Melbourne, Australia, 2007; pp. 215-222.

6. Fomin, S.I.; Ivanov, V.V. Identification and planning of mineral losses and dilution in opencast mine. Int. J. Pharm. Technol. 2016, 8, 27196-27207. 
7. Holodnyakov, G.A.; Vajnonen, N.S. Efficiency Criterion of Open-Pit Mining of Complex Deposits in the Process of Defining Quarry Boundaries. Min. Inf. Anal. Bull. 2013, 12, 52-55.

8. Potekhin, G.N.; Vohmin, S.A.; Chustugeshev, V.M.; Grigor'ev, R.V. The Practice of Design and Development of Quarries at Gold Ore Deposits of Kuranakh Ore Field. Min. Inf. Anal. Bull. 2011, 196-215. Available online: https://cyberleninka.ru/article/n/ opyt-proektirovaniya-i-razrabotki-karierov-na-zolotorudnyh-mestorozhdeniyah-kuranahskogo-rudnogo-polya/viewer (accessed on 31 August 2020).

9. Konstantinov, M.M. (Ed.) Gold Ore Deposits of Russia. Moscow; Moscow, Russia, 2010; p. 349. Available online: http://www. geokniga.org/books/2772 (accessed on 31 August 2020).

10. Minerals and Deposits of Russia and Neighboring Countries. Available online: https://webmineral.ru/deposits/item.php?id=52 3 (accessed on 31 August 2020).

11. McKee, D.J. Understanding Mine to Mill. The Cooperative Research Centre for Optimising Resource Extraction (CRC ORE). 2013. Available online: https:/ / www.911metallurgist.com/C/What-is-mine-to-mill.pdf (accessed on 31 August 2020).

12. McCaffery, K.; Mahon, J.; Arif, J.; Burger, B. BatuHijau-Controlled mine blasting and blending to optimise process production at BatuHijau. SAG2006-Circuit Design. In Proceedings of the International Conference on Autogenous and Semiautogenous Grinding Technology, Vancouver, BC, Canada, 24-28 September 2006.

13. Adel, G.; Smith, B.; Kojovic, T.; Thornton, D.; Richardson, J.M. Application of mine to mill optimization to the aggregate industry. In Proceedings of the SME Annual Meeting, St. Louis, MO, USA, 26-29 March 2006. SME of AIME.

14. Scott, A.; Morrell, S.M.; Clark, D. Tracking and quantifying value from mine to mill improvement. In Proceedings of the Value Tracking Symposium: Brisbane, Australia, 2002; Australasian Institute of Mining and Metallurgy: Melbourne, Australia, 2002; pp. 77-84.

15. Smith, M.L.; Prisbrey, K.A.; Barron, C.L. Blasting design for improved SAG mill productivity. In Proceedings of the SME Annual Meeting, Reno, NV, USA, 15-18 February 1993; pp. 93-115.

16. McKee, D.J.; Chitombo, G.; Morrell, S. The relationship between fragmentation in mining and comminution circuit throughput. Miner. Eng. 1995, 8, 1265-1274. [CrossRef]

17. Amelunxen, P.; Bennett, C.; Garreston, P.; Mertig, H. Use of geostatistics to generate an orebody dataset and to quantify the relationship between sample spacing and the precision of the throughput predictions. In Proceedings of the SAG 2001; University of British Columbia: Vancouver, BC, Canada, 2001; pp. 207-220.

18. Bye, A.R. The strategic and tactical value of a 3D geotechnical model for mining optimisation, Anglo Platinum, Sandsloot open pit. J. S. Afr. Inst. Min. Metall. 2006, 3, 1-8.

19. Wirfiyata, F.; McCaffery, K. Applied Geometallurgical Characterisation for Life of Mine Throughput Prediction at BatuHijau. In Proceedings of the SAG 2011; University of British Columbia: Vancouver, BC, Canada, 2011.

20. Bye, A.R. Case studies demonstrating value of geometallurgy initiatives. In Proceedings of the Geometallurgy 2011, Brisbane, Australia, 5-7 September 2011; Australasian Institute of Mining and Metallurgy: Melbourne, Australia, 2011.

21. Dance, A. The importance of primary crushing in mill feed size optimisation. In Proceedings of the SAG Conference, Vancouver, BC, Canada, 30 September-3 October 2001; Barratt, D.J., Allan, M.J., Mular, A.L., Eds.; University of British Columbia: Vancouver, BC, Canada, 2001; Volume I, pp. 189-202.

22. Rogers, W.; Kanchibotla, S.S.; Tordoir, A.; Ako, S.; Engmann, E.; Bisiaux, B. Solutions to reduce blast-induced ore loss and dilution at Ahafo Gold Mine in Ghana. In Proceedings of the 2012 SME Annual Meeting and Exhibit, Seattle, WA, USA, 19-22 February 2012; pp. 19-22.

23. Ebrahimi, A. The importance of dilution factor for open pit mining practices, A modified version of: An attempt to standardize the estimation of dilution factor for open pit mining projects. In Proceedings of the World Mining Congress, Montreal, QC, USA, 11-15 August 2013.

24. Gillot, P. Pit-to-Plant Optimisation at Morila Gold Mine. 2005. Available online: https://www.researchgate.net/publication/2284 27816_Pit-to-plant_optimisation_at_Morila_Gold_Mine/citations (accessed on 31 August 2020).

25. Nielsen, K.; Malvik, T. Grindability enhancement by blast-induced microcracks. Powder Technol. 1999, 105, 52-56. [CrossRef]

26. Michaux, S.; Djordjevic, N. Influence of explosive energy on the strength of the rock fragments and SAG mill throughput. Miner Eng. 2005, 18, 439-448. [CrossRef]

27. Junhyeok, P.; Jwangmin, K. Use of drilling performance to improve rock-breakage efficiencies: A part of mine-to-mill optimization studies in a hard-rock mine. Int. J. Min. Sci. Technol. 2020, 30, 179-188.

28. Fomin, S.I.; Ivanov, V.V.; Semenov, A.S.; Ovsyannikov, M.P. Incremental open-pit mining of steeply dipping ore deposits. ARPN J. Eng. Appl. Sci. 2020, 15, 1306-1311.

29. Oghazi, P.; Lund, C.; Pålsson, B.; Martinsson, O. Applying traceability in a mine-to-mill context by usingparticle texture analysis. In Proceedings of the SME Annual Meeting and Exhibit, Phoenix, AZ, USA, 28 February-3 March 2010; pp. 7-11.

30. Powell, M.; Bye, A. Beyond mine-to-mill: Circuit design for energy efficient resource utilization. In Proceedings of the Tenth Mill Operators Conference 2009; Australasian Institute of Mining and Metallurgy: Brisbane, Australia, 2009; Volume 11, pp. $357-364$.

31. Cunningham, C.V.B. The Kuz-Ram fragmentation model-20 years on. In Proceedings of the 3rd Conference on Explosives and Blasting; Holmberg, R., Ed.; European Federation of Explosives Engineers: Brighton, UK, 2005; pp. 201-210. 
32. Herbst, J.A.; Pate, W.T. Dynamic simulation of size reduction operations from mine-to-mill. In Proceedings of the Mine to Mill1998 Conference, Brisbane, Australia, 11-14 October 1998; Australasian Institute of Mining and Metallurgy: Brisbane, Australia, 1998; pp. 243-248.

33. Kanchibotla, S.S.; Morrell, A.; Valery, W.; O'Loughlin, P. Exploring the effect of blast design on SAG mill throughput at KCGM. In Proceedings of the Mine to Mill Conference; Australasian Institute of Mining and Metallurgy: Brisbane, Australia, 1998; pp. 153-158.

34. Cameron, P. The ABC of Mine to Mill and Metal Price Cycles. Available online: https://www.ausimmbulletin.com/feature/milloperations-the-abc-of-mine-to-mill-and-metal-price-cycles / (accessed on 30 November 2020).

35. Bennett, D.; Tordoir, A.; Walker, P.; La Rosa, D.; Valery, W.; Duffy, K. Throughput forecasting and optimisation at the Phu Kham Copper-Gold Operation. In Proceedings of the 12th AusIMM Mill Operators' Conference, Townsville, Australia, 1-3 September 2014; The Australasian Institute of Mining and Metallurgy: Melbourne, Australia, 2014; pp. 381-390.

36. Kristy, A.D. Achieving and Sustaining Productivity Benefits through a Mine to Mill Approach. Available online: https://www. ausimmbulletin.com/feature/achieving-sustaining-productivity-benefits-mine-mill-approach/ (accessed on 30 November 2020).

37. Cheban, A.Y. Engineering of Complex Structure Apatite Deposits and Excavating Sorting Equipment for Its Implementation. J. Min. Inst. 2019, 238, 399-404. [CrossRef]

38. Isheyskiy, V.A.; Yakubovskiy, M.M. Determination of strength reduction factor in blasted rocks versus the distance from the blast center. Gorn. Zhurnal 2016, 12, 55-59. [CrossRef]

39. Amirá, R.; Morales, N.; Cáceres, A. Analysis of the Impact of the Dilution on the Planning of Open-Pit Mines for Highly Structural Veined-Shaped Bodies. In Proceedings of the 27th International Symposium on Mine Planning and Equipment Selection-MPES 2018; Widzyk-Capehart, E., Hekmat, A., Singhal, R., Eds.; Springer: Cham, Switzerland, 2019. [CrossRef]

40. Câmara, T.R.; Leal, R.S.; Peroni, R.L. Accounting for operational dilution by incorporating geological uncertainties in short-term mine planning. DYNA 2020, 87, 178-183. [CrossRef]

41. Schofield, N.A.; Moore, J.; Carswell, J.T. Mine to Mill reconciliation-Three Case Studies. In Proceedings of the International Mine Management conference, AusIMM Bulletin, Melbourne, VIC, Australia, 20-21 November 2012; pp. 1-12.

42. Chapman, R.; Bindoff, M. The Placer Gold Mining Game; School of Earth and Environment, University of Leeds: Leeds, UK, 2010.

43. Isokangas, E.; Sonmez, B.; Wortley, M.; Valery, W. Using Smarttag to track ore in process integration and optimization projects: Some case studies in a variety of applications. J. S. Afr. Inst. Min. Metall. 2012, 112, 871-892.

44. Bamber, A.S. Integrated Mining, Pre-Concentration and Waste Disposal Systems for the Increased Sustainability of Hard Rock Metal Mining. Ph.D. Thesis, University of British Columbia, Vancouver, BC, Canada, 2008.

45. Xingwana, L. Monitoring ore loss and dilution for mine-to-mill integration in deep gold mines: A survey-based investigation. J. S. Afr. Inst. Min. Metall. 2016, 116, 149-160. [CrossRef]

46. Chaves, L.S.; Carvalho, L.A.; Souza, F. Analysis of the impacts of slope angle variation on slope stability and NPV via two different final pit definition techniques. REM Int. Eng. J. 2020, 73, 119-126. [CrossRef]

47. Cho, S.H.; Kaneko, K. Rock Fragmentation Control in Blasting; Mining and Materials Processing Institute of Japan: Sapporo, Japan, 2004; Volume 45, pp. 1722-1730.

48. La Rosa, D.; Thornton, D. Blast movement modelling and measurement. In Proceedings of the 35th APCOM Symposium, Wollongong, NSW, Australia, 24-30 September 2011.

49. Aadersen, D.C. Criteria Influencing the Mine Call Factor of a Gold Mine; Selected topics in mining engineering; Faculty of Mining Engineering, University of the Witwatersrand: Johannesburg, South Africa, 1999.

50. Engmann, E.; Ako, S.; Bisiaux, B.; Rogers, W.; Kanchibolta, S. Measurement and modelling of blast movement to reduce ore losses and dilution at Ahafo Gold Mine in Ghana. Ghana Min. J. 2013, 14, 27-36.

51. Chieregati, A.C.; Pitard, F.F. The challenge of sampling gold. In Proceedings of the Fourth World Conference on Sampling and Blending, Cape Town, South Africa, 19-23 October 2009; Southern African Institute of Mining and Metallurgy: Johannesburg, South Africa, 2009.

52. Yilmaz, E. Advances in Reducing Large Volumes of Environmentally Harmful Mine Waste Rocks and Tailings; Department of Applied Sciences, University of Québec at Abitibi-Temiscamingue (UQAT): Rouyn-Noranda, QC, USA, 2011.

53. Wang, W.; Huang, S.; Wu, X.; Ma, O. Calculation and management for mining loss and dilution under 3D visualization technical condition. J. Softw. Eng. Appl. 2011, 4, 329-334. [CrossRef]

54. Valery, W.; Jankovic, A.; LaRosa, D.; Dance, A.; Esen, S.; Colacioppo, J. Process integration and optimization from mine-to-mill. In Proceedings of the International Seminar on Mineral Processing Technology, Dhanbad, India, 10-12 October 2007.

55. Harraz, H.Z.; Hamdy, M.M.; Aly, S.A.; Abd Ella, S.A. Geochemical Exploration and Evolution of Rodruin $\mathrm{Au}-\mathrm{Zn}( \pm \mathrm{Pb} \pm \mathrm{Ag})$ Prospected Area in the Golden Triangle-Egypt. 2020. Available online: https:/ /www.researchgate.net/profile/Hassan-Harraz-2 (accessed on 26 March 2021).

56. Pease, J.D.; Young, M.F.; Johnston, M.; Clark, A.; Tucker, G. Lessons from manufacturing—Integrating mining and milling for a complex orebody. In Proceedings of the Mine to Mill 1998; Australasian Institute of Mining and Metallurgy: Melbourne, Australia; Brisbane, Australia, 1998; pp. 3-9.

57. Karageorgos, J.; Skrypniuk, J.; Valery, W.; Ovens, G. SAG milling at the fimiston plant. In Proceedings of the SAG 2001; University of British Columbia: Vancouver, BC, Canada, 2011; pp. 109-124.

58. Lam, M.; Jankovic, A.; Valery, W.; Kanchibotla, S. Maximising sag mill throughput at porgera gold mine by optimising blast fragmentation. In Proceedings of the SAG 2001; University of British Columbia: Vancouver, BC, Canada, 2001; pp. 271-287. 
59. Dance, A.; Valery, W.; Jankovic, A.; La Rosa, D.; Esen, S. Higher productivity through cooperative effort: A method of revealing and correcting hidden operating inefficiencies. In Proceedings of the SAG 2006, HPGR, Geometallurgy, International Conference on Semiautogenous Grinding Technology, Vancouver, BC, Canada, 24-28 September 2006; Volume 4, pp. 375-390.

60. Hart, S.; Valery, W.; Clements, B.; Reed, M.; Song, S.; Dunne, R. Optimisation of the Cadia Hill SAG mill circuit. In Proceedings of the SAG 2001; University of British Columbia: Vancouver, BC, Canada, 2001; pp. 12-30.

61. Erkayaoglu, M.; Dessureault, S. Improving mine-to-mill by data warehousing and data mining. Int. J. Min. Reclam. Environ. 2019, 33, 409-424. [CrossRef]

62. Standard Methodological Instructive Regulations on the Setting of Norms for Extraction Losses of Solid Commercial Minerals; USSR Committee for Supervision of the Safe Conduct of Mining Work: Moscow, Russia, 1972; 154p.

63. Fomin, S.I. Justification of Engineering Solutions in the Organization of Ore Quarry Development. J. Min. Inst. 2016, 221, 644-650. [CrossRef]

64. Tsvetkova, A.; Katysheva, E. Ecological and economic efficiency evaluation of sustainable use of mineral raw materials in modern conditions. In Proceedings of the 17 th International Multidisciplinary Scientific GeoConference SGEM 2017, SGEM 2017 Conference Proceedings, Albena, Bulgaria, 29 June-5 July 2017; Volume 17, pp. 259-266. [CrossRef]

65. Sidorov, D.V.; Ponomarenko, T.V.; Larichkin, F.D.; Vorob'yov, A.G. Economic Justification of Innovative Solutions on Reduction of Mineral Losses in the Aluminum Industry of Russia. Min. J. 2018, 6, 65-68.

66. Nevskaya, M.A.; Seleznev, S.G.; Masloboev, V.A.; Klyuchnikova, E.M.; Makarov, D.V. Environmental and business challenges presented by mining and mineral processing waste in the Russian federation. Minerals 2019, 7, 445. [CrossRef]

67. Abdollahisharif, J.; Bakhtavar, E.; Anemangely, M. Optimal Cut-Off Grade Determination Based on Variable Capacities in Open-Pit Mining. J. S. Afr. Inst. Min. Metall. 2012, 112, 1065-1069.

68. Barr, D. Stochastic Dynamic Optimization of Cut-Off Grade in Open Pit Mines. Master's Thesis, Queen's University, Queens University Kingston, Kingston, ON, Canada, April 2012.

69. Beck, D. Determination of Optimal Mining Cut-Off Grades: Mathematical Formulation and Solution Algorithm: (Case Study: Hinoba Copper Mine in The Philippines). Math. Sci. Appl. Math. 2013, 51. [CrossRef]

70. Hall, B. Cut-off Grades and Optimising the Strategic Mine Plan; The Australasian Institute of Mining and Metallurgy: Carlton, Australia, 2014; 301p. Available online: https://ru.scribd.com/document/329622693/BOOK-Cut-off-Grades-pdf (accessed on 26 March 2021).

71. Rendu, J.M. An Introduction to Cut-Off Grade Estimation, 2nd ed.; SME: Englewood, CO, USA, 2014; 159p. Available online: https:/ / books.google.ru/books?id=jK1yAgAAQBAJ\&printsec=frontcover\&hl=ru\&source=gbs_ge_summary_r\&cad=0\# $\mathrm{v}=$ onepage\&q\&f=false (accessed on 26 March 2021).

72. Bootsma, M.T.; Alford, C.; Benndorf, J.; Buxton, M.W.N. Cut-off Grade Based Sublevel Stope Mine Optimisation. In Advances in Applied Strategic Mine Planning; Dimitrakopoulos, R., Ed.; Springer: Cham, Switzerland, 2018. [CrossRef]

73. Ahmadi, M.R.; Bazzazi, A.A. Application of Meta-Heuristic Optimization Algorithm to Determine the Optimal Cutoff Grade of Open Pit Mines. Arab. J. Geosci. 2020, 13, 224. [CrossRef]

74. Whillans, P.T. Mining Dilution and Mineral Losses, An Underground Operator's Perspective. In Proceedings of the Mining Tech, Santiago, Chile, 29 July 2018.

75. Elbrond, J. Economic Effects of Ore Losses and Rock Dilution. Cim Bull. 1994, 87, 131-134.

76. Hassan, Z. Harraz Mining Dilution and Mineral Losses; Geology Department, Faculty of Science, Tanta University: Tanta, Egypt, 2019. [CrossRef]

77. Methodological Recommendations on the Content and Execution Rules of Submitted for State Expertise Materials on Techno-Economic Justification of Quality Requirements for Estimation of Mineral Deposit Reserves; Moscow, Russia, 2007; 43p. Available online: http:/ / docs.cntd.ru/document/902023112 (accessed on 30 March 2021).

78. Kaputin, Y.U.E. Cut-off Grade Justification and Optimization of Development Strategy for Open-Pit Mining, SPb., Nedra; 2017; 280p. Available online: https:/ / www.geokniga.org/bookfiles/geokniga-14-07kaputinblock.pdf (accessed on 30 March 2021).

79. Nesis, V.N. Cutoff evaluation practice in short-term gold mine planning. Gorn. Zhurnal 2017. [CrossRef]

80. Rudenko, V.V. Non-Ferrous Metals. Open-Pit Mining; Publishing House Gornaya Kniga: Moscow, Russia, 2015; 100p.

81. Aristov, I.I.; Ivanov, V.G.; Krotov, V.N. Industry-Based Guidelines on Estimation, Accounting, Standardization and Planning of Losses and Dilution in the Process of Open-Pit and Underground Mining of Radioactive, Rare and Noble Metal Deposits; Moscow, Russia, 1993; 72p. Available online: https:/ / files.stroyinf.ru/Data2/1/4293731/4293731042.pdf (accessed on 30 March 2021).

82. Owning \& Operating (O\&O) Baseline Cost Estimate Solutions. 2020. 46p. Available online: https://www.holtcat.com/ Documents /PDFs/2012PerformanceHandbook/Owning\%20\&\%20Operating\%20Costs\%20-\%20Sec\%2020.pdf (accessed on 31 August 2020).

83. Petrosov, A.A. Calculation of Metal Inventory for Selection and Economic Justification of Ore Field Development. Min. Inf. Anal. Bull. 2013, 317-325.

84. Bajmashev, Z.G.; Zagirov, N.H.; Tomilov, V.D.; Chemezov, V.V. Methodological Instructions on Standardization, Estimation and Accounting of Mining Losses and Dilution of Gold-Containing Ores (Sands); Irgiredmet: Irkutsk, Russia, 1994; 265p. 